\title{
THE EFFECT OF INDIVIDUAL COMMITMENT AND PERSONAL COMPETENCY ON ORGANIZATIONAL CITIZENSHIP BEHAVIOUR AND PERFORMANCE OF REGIONAL LEGISLATIVE MEMBERS: A STUDY AT KONAWE DISTRICT AND SOUTH KONAWE, INDONESIA
}

\author{
Anto La Ode*, Dali Nasrullah, Lecturers \\ Faculty of Economics and Business, University of Halu Oleo, Kendari, Indonesia \\ Ngadiman \\ Postgraduate Program, University of Halu Oleo, Kendari, Indonesia \\ *E-mail: laodeanto@gmail.com
}

\begin{abstract}
This study aims to determine and analyze the influence of individual commitment to organizational citizenship behavior, personal competence to organizational citizenship behavior, individual commitment to the performance of regional legislative members, personal competence to the performance of regional legislative members, and organizational citizenship behavior to the performance of regional legislative members. The populations in this study as well as a unit of analysis were 67 members of the regional legislative of Konawe Regency and South Konawe Regency. Data collection uses survey methods and analyzed by validity test, reliability test, descriptive analysis, and path analysis. The results of the study indicate that individual commitment has a positive and significant effect on organizational citizenship behavior. Personal competence has a positive and significant effect on organizational citizenship behavior. Individual commitment has a positive and significant effect on the performance of regional legislative members. Personal competence has a positive and significant effect on the performance of regional legislative members. Organizational citizenship behavior has a positive and significant effect on the performance of regional legislative members. Individual commitment and personal competence have a positive and significant effect on the performance of regional legislative members through Organizational Citizenship behavior.
\end{abstract}

\section{KEY WORDS}

Individual commitment, personal competence, organizational citizenship behavior, regional legislative members.

Individual performance is a very important topic to study, because it is inseparable from the expectations of organizations that crave continuous improvement in individual performance. Improved performance can benefit the organization and all its members. Individual performance and quality of human resources and organizational goals become elements that are not totally separated. Effective measures of performance are those that are in accordance with organizational standards and synergize with organizational goals. Performance can also be the work of a person or group of people in accordance with applicable standards (Rivai, 2004).

Organizational performance is largely determined by individual performance, this indicates that the better the individual's performance towards organizational goals will be easily achieved and the realization of effectiveness and efficiency in the organization (Gibson, 1987). Realizing reliable human resources and having the optimal level of work productivity is a classic problem faced by all organizations. Optimal performance improvement depends on the organization's ability to empower individuals. The potential of human resources owned by the organization if managed professionally will support the success of the organization. Changes in the organizational environment both internally and 
externally affect an organization's ability to improve its performance. Performance is closely related to individual achievement of the tasks and work provided.

The issue of individual performance was the main concern of the Members of the Konawe District Representative Council and Konawe Selatan District. The performance of the council in carrying out its legislative functions has always been a special concern of the community because it is entrusted with the mandate of the council members to be able to prosper the community. Legislative institutions have 3 general functions, namely: (1) legislative functions (functions of making legislation), (2) budget functions (functions for preparing budgets), (3) monitoring functions (functions to oversee executive performance). Capacity of Human Resources is the ability of executive and legislative members to carry out their respective functions and roles in the process of policy formulation in regional financial management.

The Konawe Regional Representative and the Konawe Selatan District as one of the regional people's representative institutions in Konawe District and South Konawe Regency are administrators who have the duty to provide public services in accordance with the mandate of the law. Various work programs of the institution will be successful if supported by the realization of an increase in Organizational Citizenship Behavior (OCB) and individual performance. OCB is an informal rule that is voluntary. With the existence of OCB, individuals in the organization are expected to be more integrated with their work environment. OCB is behavior carried out by individuals that increases the effectiveness of the organization, but is not the formal responsibility of the person. OCB has an impact on what is good for the organization. Positive behavior can produce effective intentions and results, but if negative individual behavior will produce bad intentions and results (Makeover, 2003). The organization wants individuals who are willing to do tasks that are not listed in the job description. According to Robbins and Judge (2008), the facts show that individuals who have a good OCB will have better performance.

Individual commitment to the organization is often a very important issue, especially in the organization of the Regional Representatives Council. The Ibrahim and Aslinda Study (2013) explained that commitment contributes to the level of organizational success and influences better OCB. Ahimbisibwe and Nangoli (2012) also emphasized the importance of individual commitment to achieving the best performance. Prasetio, et al (2017) assess that $\mathrm{OCB}$ is determined by job satisfaction and commitment. Nevertheless, there are still individuals who have not understood the meaning of commitment correctly. Such understanding is very important in order to create better working conditions of the Regional People's Legislative Assembly so that the organization can run efficiently and effectively, but more importantly, they want to give the best to the community, even willing to do something beyond the organizational boundaries.

Performance is a function of competence. To complete a task or work, individuals must have a certain degree of willingness and level of personal competence. Willingness and individual skills are not effective enough to do something without a clear understanding of what is done and how to do it. In addition to the high commitment of individuals, achieving organizational goals is also influenced by the personal competencies of individuals. If individuals have high work competencies, the organization will not experience difficulties in achieving its goals, but if the personal competencies of individuals are low, then this will be a "stumbling block" for the organization in achieving its goals. This study aims to determine the level of influence of individual commitment and personal competence on the performance of members of the regional legislative through OCB.

\section{LITERATURE REVIEW}

Behavioral accounting provides a set of measurement concepts and performance achievement innovations from a set of business processes and decision making policies. Three perspectives based on human behavior namely psychology, sociology and social psychology make a major contribution to behavioral science (Robbins, 2003). Behavioral accounting focuses more on the relationship between human behavior and the accounting 
system (Menezes, 2008). Sociology, psychology, and social psychology factors are relevant to behavioral accounting. These factors include attitude, motivation, perception, learning, and personality (Siegel and Marconi, 1989).

Accounting, usually only focused on reporting financial information. In the last few decades managers and professional accountants began to know the need for additional economic information produced by the accounting system. Therefore economic information can be added by not only reporting financial data, but also non-financial data related to the decision making process. Based on this condition, it is only natural that accounting should include behavioral dimensions of various parties related to the information produced by the accounting system.

The scope of behavioural accounting can be categorized into the influence of human behaviour based on the design, construction and use of accounting systems. This field of behavioural accounting has to do with management attitudes and philosophies that influence the nature of accounting controls that function within the organization. The effect of accounting systems on human behaviour, this scope is concerned with how the accounting system influences motivation, productivity, decision making, job satisfaction and collaboration. Methods for predicting and strategies to change human behaviour, the scope of behavioural accounting has a relationship with the way the accounting system is used so that it affects behaviour (Lubis, 2010).

Commitment is the ability and willingness to harmonize personal behavior with the needs, priorities and goals of the organization. This includes ways to develop goals or meet organizational needs, which essentially prioritize the organization's mission rather than personal interests (Soekidjan, 2009). According to Allen and Meyer (1991), commitment can also mean the individual's strong acceptance of the goals and values of the organization, and individuals strive and work and have a strong desire to remain in the organization. Furthermore, individual commitment is a sense of identification, involvement and loyalty expressed by an employee towards the organization, as well as the conditions in which employees are very interested in the goals, values, and objectives of their organization. Commitment to the organization means more than just formal membership, because it includes the attitude of liking the organization and willingness to seek a high level of effort for the interests of the organization for the achievement of goals (Kuntjoro, 2002; Zurnali, 2010). The factors that influence organizational commitment are personal, situational and position. Personal has certain personality traits that are meticulous, extroverted, positive (optimistic), and tends to be more committed (Dyne and Graham, 2005). In general, a strong commitment to the organization has been shown to increase job satisfaction, reduce absenteeism and improve performance (Soekidjan, 2009).

At first there were only two types of competency definitions that developed rapidly, namely competencies defined as a description of what someone should know or do in order to carry out their work well, known as technical or functional competencies (technical / functional competencies) or can be called the terms hard skills and competencies that describe how one is expected to behave in order to carry out good work known as behavioral competencies or can be called soft competency (soft skills / soft competency) (Hutapea and Thoha (2008). According to Spencer and Spencer (1993), there are five types of competency characteristics that are the foundation for behaving and thinking, namely: (1) motives, traits, self-concepts, knowledge, and skills Personal competencies in the perspective of public organizations specifically the House of Representatives, is inseparable from the concept put forward by several previous researchers including Afiah (2010), Wahyuningsih and Sakti (2010), and Labay (2012), that personal competence is the ability, knowledge, insight, and attitude as people's representatives which are used as guidelines in carrying out job responsibilities in accordance with the standards set by the Regional Legislative, so that individual members of the Regional Representative can think, behave and act in accordance with the needs of the community.

Many researchers have different terms in calling Organizational Citizenship Behavior (OCB). Some researchers refer to OCB as Prosocial Behavior or Extra-role Behavior and most often call it OCB (Organizational Citizenship Behavior). The idea of Organizational 
Citizenship Behavior was introduced by Organ in the early 1980s, but if it traces far back, Barnard (1938) has used a similar concept of willingness to cooperate. OCB is innovative and spontaneous behaviors which state that there needs to be more behavior that is not only in accordance with what has been standardized to be more flexible and effective. William and Anderson (1991) interpret the OCB theory, there are two that distinguish between in-role behavior and extra-role behavior, where in-role behavior is the behavior of employees who only fulfill the responsibilities specified in their job descriptions. While the extra-role behavior is if the employee gives a performance that exceeds the limits given in his job description. Citizenship behavior can improve organizational performance because this extra-role behavior is a "lubricant" of social machinery in the organization, which can be interpreted that the presence of this behavior can reduce the occurrence of conflicts between employees and improve efficiency in the workplace (Borman and Motowildo, 1993)

Performance is a record of the results obtained from certain job functions or activities over a period of time (Dessler, 2009). Performance is the level of achievement of results for the implementation of certain tasks or a collection of work results according to quantity, quality, efficiency and effectiveness of work in achieving goals (Simanjuntak, 2005; Davis, 2005). Performance measures can be used for a number of different purposes. These needs can start from simply considering the current level of performance, the future or carefully monitoring a process that is taking place. Measuring performance measures is identifying those measures that will really help achieve the desired results, then convey them to the right people. Performance assessment is intended to improve employee performance by improving performance (Wibowo, 2007).

\section{METHODS OF RESEARCH}

This research was conducted in Konawe District and South Konawe Regency, Southeast Sulawesi Province. The population in this study as well as the unit of analysis were the members of the Konawe District Regional Representative 30 people and South Konawe District as many as 35 people in 2017 so the total population was 65 people. Data collection methods used are survey methods. The analysis technique used in this study is to test the validity, reliability test, descriptive analysis, and path analysis.

\section{RESULTS AND DISCUSSION}

The causality relationship developed in the hypothesis in the research model, which was tested through the $t$ test (critical ratio). The following table will show the regression coefficient values (regression wight estimate) and critical ratio (t-count). The hypothesis will be accepted if the critical ratio (t-count) is greater than 1,960 or the $p$ value $\leq 0.05$. The path analysis model proposed in this study includes 7 (seven) lines of direct and indirect influence between the independent variable and the dependent variable.

Table 1 - Path analysis results

\begin{tabular}{|c|c|c|c|c|c|c|}
\hline \multicolumn{7}{|c|}{ Direct Effects } \\
\hline \multicolumn{2}{|l|}{ Variable } & Estimate & Standard Error & $\begin{array}{c}\text { Critical } \\
\text { Ratio }\end{array}$ & $\begin{array}{c}\text { P- } \\
\text { Value }\end{array}$ & $\begin{array}{l}\text { Decision } \\
\text { Hypothesis }\end{array}$ \\
\hline \multicolumn{2}{|c|}{ Individual commitment $\rightarrow$ OCB } & 0,396 & 0,085 & 4,682 & 0,000 & H1- Received \\
\hline \multicolumn{2}{|c|}{ Personal competency $\rightarrow$ OCB } & 0,252 & 0,097 & 2,599 & 0,009 & H2- Received \\
\hline \multicolumn{2}{|c|}{ Individual commitment $\rightarrow$ Performance } & 0,232 & 0,108 & 2,156 & 0,031 & H3- Received \\
\hline \multicolumn{2}{|c|}{ Personal competency $\rightarrow$ Performance } & 0,259 & 0,111 & 2,330 & 0,020 & H4- Received \\
\hline \multicolumn{2}{|l|}{ OCB $\rightarrow$ Performance } & 0,502 & 0,143 & 3,520 & 0,000 & H5- Received \\
\hline \multicolumn{7}{|c|}{ Indirect Effects } \\
\hline Independent Variable & \multicolumn{2}{|l|}{$\begin{array}{l}\text { Intervening } \\
\text { Variable }\end{array}$} & $\begin{array}{l}\text { Dependent } \\
\text { Variable }\end{array}$ & Estimates & $\begin{array}{c}\text { P- } \\
\text { Value }\end{array}$ & $\begin{array}{c}\text { Decision } \\
\text { Hypothesis }\end{array}$ \\
\hline Individual commitment & \multicolumn{2}{|l|}{ OCB } & Performance & & 0,005 & H6- Received \\
\hline Personal competency & OCB & \multicolumn{2}{|c|}{ Performance } & & 0,036 & H7- Received \\
\hline
\end{tabular}

Source: Data processed. 
The effect of individual commitment to OCB based on estimates (coefficient) value of 0.396, the level of influence is significant based on the $p$-value of $0.000<0.05$. These results indicate that the increase in the quality of individual commitments will have an impact on increasing OCB assuming other factors that influence individual commitment are considered constant. The magnitude of the coefficient value of individual commitment variables towards OCB reflects the high contribution of these independent variables in determining the high and low OCB. The statistical results show that the first hypothesis $(\mathrm{H} 1)$ was declared accepted. The results of this study are appropriate and relevant to the findings of Fitria, et al. (2015) and Kurniawan (2015) which reveal a strong influence between commitment to OCB in the organization. Organizational Citizenship Behavior (OCB) is important to overcome the complexity of organizational problems in the public sector, the findings of Ibrahim and Aslinda (2013) positive role of commitment and significant influence on OCB. While the results of this study are different from the findings of Darmawati, et al. (2013) that commitment does not have a significant effect on OCB. High commitment is positively correlated with high motivation and increased performance, independence and "Self Control", as well as loyalty to the organization. Commitment as an ability and willingness to harmonize personal behavior with organizational needs, priorities and goals. This includes ways to develop goals or meet organizational needs, which essentially prioritize the organization's mission rather than personal interests (Soekidjan, 2009). Individual commitment is a condition where employees are very interested in the goals, values, and objectives of their organization. Commitment to the organization means more than just formal membership, because it includes the attitude of liking the organization and the willingness to seek a high level of effort for the interests of the organization for the achievement of goals. According to Zurnali (2010), commitment is a strong and close feeling of a person towards the goals and values of an organization in relation to their role in efforts to achieve these goals and values. Organizational commitment can be influenced by personal, situational and positional factors (Dyen and Graham, 2005).

The effect of personal competence on OCB is based on estimates (coefficients) of 0.252 , the level of influence is significant based on the $p$-value of $0.009<0.05$. These results indicate that the increase in the quality of personal competencies will have an impact on increasing OCB assuming other factors that affect personal competence are considered constant. The magnitude of the coefficient value of the personal competency variable on OCB reflects the high contribution of these independent variables in determining the high and low OCB. The statistical results show that the second hypothesis $(\mathrm{H} 2)$ is declared accepted. The significant influence of personal competence on OCB is also in line with the findings of Kurniawan (2014) stating that competence and commitment have a significant effect on OCB. Human resource competencies, which are considered as factors that create innovation and value for organizations, are very important for organizations (Serima et al., 2014). While the results of research from Suhardi and Syaifullah (2017) have different findings, that competence does not significantly influence organizational citizenship behavior. Competence refers to behavioral characteristics that describe the motives, traits, self-concepts, values, knowledge and skills of a person in carrying out their work properly. These characteristics are not seen and illustrated in the unity of behavior in the form of attitudes. But elements of competency can be mentioned, namely knowledge, skills, and attitude. There are five types of competency characteristics that form the basis for behavior and thinking, namely motives, traits, self-concepts, knowledge, and skills (Spencer and Spencer, 1993).

The effect of individual commitment on performance based on estimates (coefficient) value of 0.232 , the level of influence is significant based on the $p$-value of $0.031<0.05$. These results indicate that the increase in the quality of individual commitments will have an impact on improving performance assuming other factors that influence individual commitment are considered constant. The magnitude of the coefficient value of individual commitment variables on performance reflects the high contribution of these independent variables in determining the level of performance. The statistical results show that the third hypothesis $(\mathrm{H} 3)$ is declared accepted. Significant influence between individual commitment to board performance also has similarities with the research findings of Supiyanto (2015), 
and Irefin and Mechanic (2014), but the results of different studies are suggested by Parinding (2015) that commitment negatively affects performance. Similarly, the findings of Nydia (2012) and that commitment does not affect performance, Srimulyani (2017) also explains its findings that commitment has a negative and not significant effect on performance. Commitments can be owned by individuals because of several influencing factors, thus means that individual commitments will not just happen but occur gradually, to keep individuals always committed, the organization must have a strategy to maintain and increase individual commitment.

The effect of personal competence on performance based on estimates (coefficients) of 0.259 , the level of influence is significant based on the $p$-value of $0.020<0.05$. These results indicate that the increase in the quality of personal competence will have an impact on improving performance assuming other factors that affect personal competence are considered constant. The magnitude of the coefficient value of the personal competency variable on performance reflects the high contribution of these independent variables in determining the level of performance. The statistical results show that the fourth hypothesis $(\mathrm{H} 4)$ is declared accepted. The influence of personal competence on board performance was also investigated by Ratnasari (2016), but having different findings, namely competence did not have a significant effect on the performance of the quality department employees. The findings of Supiyanto (2015) actually emphasize that compensation, competence and organizational commitment both simultaneously and partially have a significant effect on employee performance. Labay, et al. (2012) stated that there was a significant and positive influence between competence, skills, and work motivation on the performance of board members. Competence as a behavioral dimension behind performance is competent. Named as behavioral competency because to explain it explains its role well. If behavior is defined as competence, it can be classified as: 1) understanding what needs to be done in the form of reasons: critical reasons, strategic capabilities, and business knowledge, 2) making work done through encouragement, proactive approach, confidence, control, flexibility, interest in effectiveness, persuasion and influence, and 3) bringing people with motivation, interpersonal skills, interests with results, persuasion, and influence (Armstrong and Baron, 1998). The competency category consists of task achievement, relationships, personal attributes, managerial, and leadership (Zwell, 2000). Organizations have the potential to show optimal performance if they are supported by people who work optimally as well. The optimal contribution of people in the organization is only possible if these people have the awareness and ability of their tasks, and this can be done if the person has sufficient competence in accordance with the field of work.

The effect of OCB on performance based on estimates (coefficient) value of 0.502 , the level of influence is significant based on the p-value of $0.000<0.05$. These results indicate that the increase in the quality of $\mathrm{OCB}$ will have an impact on improving performance assuming other factors that influence OCB are considered constant. The magnitude of the OCB variable coefficient value on performance reflects the high contribution of these independent variables in determining the level of performance. The statistical results show that the fifth hypothesis (H5) is declared accepted. Moideenkutty, et al. (2005) explained that OCB plays an important role in increasing work productivity. Employees satisfied with their jobs tend to often adopt organizational citizenship behaviors (Pavalache-llie, 2014). Wicaksono's research (2012) also corroborates the results of this study that OCB has a positive and significant effect on performance. Meanwhile, the Kilinc study (2014) states that the influence between the dimensions of reasonableness (courtesy) of organizational citizenship (OCB) on employee performance is stated to be insignificant. Citizenship behavior or extra-role behavior is different from in-role behavior where behaviors are associated with extrinsic rewards or incentive rewards that are reward and punishment. While the behavior of extra-roles is generally free from rewards, because this behavior arises from different motives for personal motivation such as feeling as a "part" of the organization and "feeling possessed" and feeling satisfied when it can do "something more" to the organization, feeling dead organization is his responsibility. With citizenship behavior can improve organizational performance because this extra-role behavior is a "lubricant" of social 
machinery in the organization, which can be interpreted that the presence of this behavior can reduce the occurrence of conflicts between employees and improve efficiency in the workplace (Borman and Motowildo, 1993).

The indirect effect between individual commitment to performance through OCB shows estimates value of 0.199 (19.9 percent) and probability value (sobel test) of $0.005<0.050$. This shows that individual commitment has an important role in improving performance significantly through OCB. The statistical results show that the sixth hypothesis $(\mathrm{H} 6)$ is declared accepted. The research of Ibrahim and Aslinda (2013), Prasetio, et al. (2017), Adianita, et al. (2017), and Kurniawan (2014) confirm that individual commitment influences performance through OCB. Commitment formed by various strategies does not mean that there is no benefit, the benefits of commitment in the organization are as follows: (a) Workers who truly show high commitment to the organization have a far greater possibility of showing a high level of participation in the organization; (b) Having a stronger desire to continue working for the current organization and can continue to contribute to the achievement of goals; (c) Fully involve themselves in their work, because the work is a key mechanism and individual channel to contribute to the achievement of organizational goals. With the commitment to the organization, individuals have benefits such as sincere and happy when involving themselves in work, have a stronger desire to continue working in the current organization and can continue to contribute to achieving goals and have far greater possibilities to show high level of participation in the organization.

The indirect effect of personal competence on performance through OCB shows an estimate value of 0.126 (12.6 percent) and probability value (sobel test) of $0.036<0.050$. This shows that personal competence has an important role in improving performance significantly through OCB. The statistical results show that the seventh hypothesis $(\mathrm{H} 7)$ is declared accepted. Kurniawan's research (2014), Serima, et al. (2014), Supiyanto (2015), and Labay, et al. (2012) asserted that personal competence influences performance through OCB. Organizations have the potential to show optimal performance if they are supported by people who work optimally as well. The optimal contribution of people in the organization is only possible if these people have the awareness and ability of their tasks, and this can be done if the person has sufficient competence in accordance with the field of work. This means that, these people are able to work with the best achievements at this time and in the future, both in stable situations and in changing situations, without interfering with the work of others. Thus, a measure of organizational achievement includes the dimensions of time, situation, and contribution and their impact on the work of others or companies. The right competencies, which are factors that determine achievement excellence, can be owned by the organization if the organization has a strong foundation, which is reflected in all processes that occur within the organization. Organizations must have core competencies that are strong and in accordance with their core business. Core competencies are those that belong to all members of the organization that make members of the organization different from other organizations. Core competencies are usually a component forming the organization's mission and culture. Core competencies must be strengthened by the competencies of departments in the organization.

\section{CONCLUSION}

Increasing the quality of individual commitment influences the increase in OCB assuming other factors that influence individual commitment are considered constant. The magnitude of the coefficient value of individual commitment variables towards OCB reflects the high contribution of these independent variables in determining the high and low OCB. Improving the quality of personal competence has an effect on increasing OCB assuming other factors that influence personal competence are considered constant. The magnitude of the coefficient value of the personal competency variable on OCB reflects the high contribution of these independent variables in determining the high and low OCB. Increasing the quality of individual commitments influences performance improvement by assuming other factors that influence individual commitment are considered constant. The magnitude 
of the coefficient value of individual commitment variables on performance reflects the high contribution of these independent variables in determining the level of performance. Improving the quality of personal competencies influences the increase in performance assuming other factors that influence personal competence are considered constant. The magnitude of the coefficient value of the personal competency variable on performance reflects the high contribution of these independent variables in determining the level of performance. Improving the quality of OCB will have an effect on the effect of performance assuming other factors that influence OCB are considered constant. The magnitude of the OCB variable coefficient value on performance reflects the high contribution of these independent variables in determining the level of performance. Individual commitment has an important role in improving performance significantly through OCB. The role of OCB as an intervening variable is very important in increasing individual commitment to the performance of board members. Personal competence has an important role in improving performance significantly through OCB. The role of OCB as an intervening variable is very important in improving personal competency towards the performance of regional legislative members.

\section{REFERENCES}

1. Adianita, U.S., Mujanah, S., \& Candraningrat. 2017. Employee Competence, Emotional Quotient and Self Efficacy Effects on Organizational Citizenship Behavior and Employee Performance at Indomobil Group in Surabaya. Journal of Research in Economics and Management, Volume 17, No. 1, January - June.

2. Afiah, N. N. 2010. Effect of Competence of Members of the Regional Legislative Assembly and Regional Government Apparatus, Implementation of Accounting Information Systems, Budgeting and Financial Information Quality Against Principles of Good Local Government Governance: Survey of Districts / Cities in West Java. Journal of Social Sciences and Humanities, Vol. 12, No. 1.

3. Ahimbisibwe, A \& Nangoli, S, 2012. Project Communication, Individual Commitment, Social Networks, and Perceived Project Performance. Journal of African Business, Vol. 13, Issue 2.

4. Allen, N.J \& J.P. Meyer. 1991. The Measurement and Antecedents of Affective, Continuous and Normative Commitment to the Organizational. Journal of Occupational Psychology. 63 (1): 1-. 18.

5. Armstrong, M, \& Baron, A. 1998. Performance Management: The New Realities, Institute of Personnel and Development. New York.

6. Barnard, C. I. 1938. The Functions of the Executive. Harvard University Press, Cambridge.

7. Borman, W. C. \& Motowidlo, S.J. 1993. Expanding the Criterion Domain to Include Elements of Contextual Performance. In Schmitt, N. and Borman, W.C., Eds., Personnel Selection in Organizations, Wiley, New York, 71-98.

8. Darmawati, A., L.N. Hayati, \& D. Herlina. 2013. Effects of Job Satisfaction and Organizational Commitment on Organizational Citizenship Behavior. Economia Journal, Vol. 9, No. 1.

9. Davies, K. 2005. Human Behavior at Work Organizational Behavior. New Delhi: McGraw Hill Publishing Company.

10. Dessler, G. 2009. Human Resource Management. Jakarta: Index.

11. Dyne, V.L, \& Graham, J.W. 2005. Organizational Citizenship Behavior; Construct Redefinition Measurement and Validation. The Academy.

12. Fitria, R.M., R.S. Dewi, \& S.K.T. Febriana. 2015. Role of Organizational Commitment to Organizational Citizenship Behavior in Nurses. Ecopsy Journal, Vol. 2, No. 1.

13. Gibson, L.J. 1987. Organizational Behavior. Jakarta: Erlangga.

14. Hutapea, Parulian., \& Nurianna T. 2008. Communication Competence Plus: Theory, Design, Cases and Applications for Dynamic HR and Organizations. Jakarta: Gramedia. 
15. Ibrahim, M. A., \& Aslinda, A. 2013. Relationship between Organizational Commitment and Organizational Citizenship Behavior (OCB) at Government-Owned Corporation Companies. Journal of Public Administration and Governance, Vol. 3, No. 3.

16. Irefin, P., \& Mechanic, M.A. 2014. Effect of Employee Commitment on Organizational Performance in Coca Cola Nigeria Limited Maiduguri, Borno State. IOSR Journal of Humanities and Social Science, Volume 19, Issue 3, Ver. I, pp. 33-41.

17. Kılınç, E., \& Hatice Ulusoy. 2014 Investigation of Organizational Citizenship Behavior, Organizational Silence and Employee Performance at Physicians and Nurses, and the Relationship among them. Business Management Dynamics, Vol.3, No.11, Nov 2014, pp.25-34.

18. Kuntjoro, H. Zainuddin S. 2002. Organizational Commitment. Jakarta. http://www.epsikologi.com/masalah/250702.htm.

19. Kurniawan, A. 2014. The Influence of Competency and Management Citizenship Behavior and Its Impact to Employee Productivity Based on Perception of Supervisors: A Survey at Star Hotels in West Java. Journal of Business and Economics, ISSN 21557950, Vol. 5, No. 8. pp. 1430-1441.

20. Kurniawan, A. 2015. Effect of Organizational Commitment on Organizational Citizenship Behavior (OCB) of PT. X Bandung. Management Journal, Vol. 15, No.1.

21. Labay, I., Sujianto, \& Zulkarnaini. 2012. Knowledge, Skills, Work Motivation, and Performance of DPRD Member Competencies. Public Policy Journal, Volume 3, Number 2, October, p. 59-141.

22. Lubis, Ershad. 2010. Banks and Other Financial Institutions. Medan: USU Press.

23. Makeover, B. 2003. Examining the Employee-Customer Chain in the Fitness Industry. Dissertation. Florida: The Florida State University, College of Education.

24. Menezes, Alvaro Amaral. 2008. Analysis of the Impact of Locus of Control on the Performance and Job Satisfaction of Internal Auditors (Research on Internal Auditors in Central Java). Widyatama University.

25. Moideenkutty, U., Gary, B., Ravi, K \& Ahamedali, N. 2005. Relationship of Organization Citizenship Behavior and Objective Productivity to Managerial Evaluations of Performance in India. International Journal of Commerce and Management, Vol. 15 Issue: $3 / 4$, pp.221-229.

26. Nydia, Y. T. 2012. Effect of Organizational Commitment on Employee Performance at Coco Pertamina SPBU Field. University of Indonesia.

27. Parinding, R. G. 2015. Analysis of the Effect of Affective Commitment, Continuous Commitment and Normative Commitment on Employee Performance at PT. Pegadaian (PERSERO) Ketapang Branch. e-Journal of MAGISTRA Management Sciences Vol. 1. Narotama University Surabaya.

28. Pavalache-llie, Mariela. 2014. Organizational Citizenship Behavior, Work Satisfaction and Employees' Personality. Procedia - Social and Behavioral Sciences, 127, 489-493.

29. Prasetio, A. P., Yuniarsih, T. \& Ahman, E. 2017. Job Satisfaction, Organizational Commitment, and Organizational Citizenship Behavior in State-owned Banking. Universal Journal of Management, 5 (1): 32-38.

30. Ratnasari, Sri L. 2016. Effect of Competence and Compensation on Employee Performance of the Quality Assurance Department of PT. PEB Batam. Proceedings of the National Economic and Business Seminar \& FEB UMSIDA Call For Paper.

31. Rivai, V. 2004. Human Resource Management for Companies: From Theory to Practice. Jakarta: PT Raja Grafindo Persada.

32. Robbins, Stephen P. 2003. Organizational Behavior. Jakarta: Index.

33. Robbins, Stephen.P. 2008. Organizational Behavior. Tenth Edition. Jakarta: Salemba Empat.

34. Robbins, Stephen P., and Timothy A. Judge. 2009. Organizational Behavior, 13th Edition. Pearson Education, Inc., Upper Saddle River, New Jersey, pp. 209-586.

35. Serima, H., Demirbağ, O \& Yozgat, U. 2014. The Effects of Employees' Perceptions of Competency Models on Employability Outcomes and Organizational Citizenship Behavior 
and the Moderating Role of Social Exchange in this Effect. Procedia - Social and Behavioral Sciences, 1501101 - 1110.

36. Siegel, G., \& Marconi, H. R. 1989. Behavioral Accounting. South Western Publishing Co.

37. Simanjuntak, P.J. 2005. Management and Performance Evaluation. Jakarta: FE UI.

38. Soekidjan. 2009. Management of Human Resources. Jakarta: Bumi Aksara.

39. Srimulyani, I., R. Murniningsih \& Bayu Sindhu Raharja. 2017. Effect of Organizational Commitment on Employee Performance with Organizational Citizenship Behavior (OCB) as a Moderating Variable. The 6th University Research Colloquium 2017. Muhammadiyah University Magelang.

40. Suhardi \& Syaifullah. 2017. Effect of Motivation, Competence, Work Environment, Compensation on Organizational Citizenship Behavior and Employee Insurance Performance in Riau Islands Province. Benefita Journal, 2 (1) (55-71).

41. Supiyanto, Y. 2015. Effects of Compensation, Competence and Organizational Commitment on Satisfaction and Performance. Economia Journal, Vol. 11, No.2.

42. Spencer, Lyle \& Signe M. Spencer. 1993. Competence at Work, Models For Superior. Performance. Canada: John Wiley \& Sons, Inc.

43. Wahyuningsih, T., \& Sri Wahyu K.S. 2010. Competency Study of Regency Regional Representatives Members - Sukabumi City, West Java Province. Journal of Organization and Management, Vol. 6, No. 1, March, 58-73.

44. Wibowo. 2007. Performance Management. Jakarta: PT. Raja Grafindo Persada.

45. Wicaksono, D.S. 2012. Analysis of the Effect of Organizational Citizenship Behavior (OCB) and Organizational Commitment on Performance with Mediation of Job Satisfaction (Study at PT. BPR Nusamba Cepiring). Students' Journal of Accounting and Banking, Vol. 1, No. 1.

46. Williams, L. J., \& Anderson, S. E. 1991. Job Satisfaction and Organizational Commitment as Predictors of Organizational Citizenship and In-role Behaviors. Journal of Management, 17, 601-617.

47. Zurnali, Cut. 2010. Learning Organization, Competency, Organizational Commitment, and Customer Orientation: Future Knowledge Worker-Framework for Human Resource Management Research. Bandung: Unpad Press.

48. Zwell, Michael. 2000. Creating a Culture of Competence. New York: John Wiley. \& Sons, Inc. 